\title{
Innate versus adaptive immunity in kidney immunopathology
}

\author{
Hans-Joachim Anders
}

\begin{abstract}
Most kidney disorders involve some degree of inflammation, i.e. induction of pro-inflammatory mediators and leukocyte recruitment. But what are the factors that determine inflammation as a trigger or a consequence of kidney injury? Which types of renal inflammation can be targeted by the novel more selective immunosuppressive and anti-inflammatory agents? How to dissect the mechanisms behind innate and adaptive immune responses that are orchestrated inside or outside the kidney but both cause renal immunopathology i.e. renal inflammation? How to dissect leukocytic cell infiltrates into pro-inflammatory leukocytes from anti-inflammatory and pro-regenerative leukocytes? How to dissect leukocytes that support epithelial repair from those that promote renal fibrosis. The term 'renal inflammation' has moved far beyond the descriptive category of 'mixed leukocytic cell infiltrates' as commonly described in kidney biopsies. It is time to face the complexity of renal inflammation to finally benefit from the new age of novel immunomodulatory medicines.
\end{abstract}

Keywords: Glomerulonephritis, Acute kidney injury, Chronic kidney injury, Chemokines, Macrophages, B cells, T cells

Inflammation is one of several danger response programs that helps to control dangers that disrupt kidney homeostasis $[1,2]$. Historically, inflammation was clinically defined by the combination of rubor, calor, dolor, tumor, and functio laesa. In the 18th and 19th century the concept of cellular pathology evolved and since then leukocytic cell infiltrates were taken as a hallmark of what we call tissue inflammation. Until today the presence of increased numbers of leukocytes in body fluids such as blood, liquor, urine or within joints or the pleural and peritoneal cavity is taken as a biomarker of inflammation. Based on the work of Jenner, Behring, Kitasato, Ehrlich, and Lahnsteiner immunological memory was discovered and first thought to solely depend on humoral factors, the immunoglobulins [3]. This view was subsequently refined by the discovery of the $\mathrm{T}$ and $\mathrm{B}$ lymphocytes and later by the identification and characterization of antigen-presenting cells [3]. In the 20th century research in the field of immunology was dominated by the growing understanding of the complexity of antigen-specific 'adaptive' immunity, immune tolerance, and immune memory, a field much stimulated by

Correspondence: hjanders@med.uni-muenchen.de

Renal Division, Medizinische Klinik und Poliklinik IV, Klinikum der Universität München, Ziemssenstr. 1, D-80336, Munich, Germany the implementation of organ transplantation into clinical practice [3].

Despite seminal advances on kidney physiology and pathology in the 19th century nephrology as a distinct medical discipline did not evolve before the second part of the 20th century, largely driven by technical advances in renal replacement therapies $[4,5]$. The growing understanding of renal inflammation as a pathway to chronic kidney disease was dominated by the pathophysiological concepts of immune complex disease, antigen-specific immunity in interstitial nephritis, and alloimmunity of the kidney allograft [6]. It was not before the discovery of the complement system, the Fc receptors, and the cytokines that innate immunity became a central topic of interest [6]. Chemokines raised further attention on the mechanisms of neutrophil and macrophage recruitment, which, obviously, contributed to immunopathology of the kidney in an antigen-independent manner [7].

However, upon the discovery of the Toll-like receptors [8], the RIG-like helicases [9], and the inflammasomes [10] in the 1990s the scientific community shifted its full attention towards the innate immune system [11]. The innate and the adaptive immune system are different from many points of view as listed in Table 1 . The evolution of the innate immune system dates back to the first single 
Table 1 Differences in innate and adaptive immunity

\begin{tabular}{lll}
\hline & Innate immunity & Adaptive immunity \\
\hline Recognition receptors (R) & Complement-R & B cell receptors \\
& Mannose-R & T cell receptors \\
& Toll-like-R & MHC I \\
& Inflammasomes & MHCII \\
& Low affinity immunoglobulins & High affinity lgG \\
Receptor clonality & Non-clonal & clonal \\
Receptor genes & Single gene, no rearrangement required & Encoded in gene segments Rearrangement required \\
Receptor agonists & Molecular patterns & Antigenic epitopes \\
Time delay of response & Immediate & Delayed \\
Effector mechanism & Opsonization, phagocytosis, granuloma formation, & Clonal expansion of antigen-specific B and T cells, \\
& leukocyte recruitment, complement lysis, & antigen-specific immunoglobulins \\
Paradigmatic kidney diseases & Unflammation, healing responses & \\
& glomerulosclerosis, tubulointerstitial fibrosis, & IC glomerulonephritis, allograft rejection, interstitial nephritis \\
& crystal nephropathies C3 glomerulopathy & \\
\hline
\end{tabular}

IC immune complex.

cell organisms, while adaptive immunity evolved not before the appearance of the jawed cartilaginous fish around 500 million years ago [12]. Since then evolution has imprinted a tight connection between innate and adaptive immune reponses for the sake of most efficient pathogen control [13]. But what is the impact of the evolving understanding of innate immunity on renal science?

Most kidney diseases involve inflammation. Adaptive immunity predominates in kidney disorders that are related to foreign antigens (e.g. in postinfectious glomerulonephritis) or autoantigens (Table 1). Autoantigens may come from within the kidney (e.g. in anti-glomerular basemement membrane glomerulonephritis or renal transplantation) or from extrarenal sources (e.g. in IgA nephropathy). As such immune complex-related glomerulonephritis, allograft rejection or antigen-mediated interstitial nephritis are paradigmatic disorders in which systemic immunosuppression can suppress the immune responses that are regulated outside the kidney.

Innate immunity is the predominant immune response in antigen-independent types of inflammation, such as toxic, ischemic, or traumatic kidney injury, which often present as acute kidney injury where the inflammatory component largely determines renal immunopathology and dysfunction [14]. For example, experimental interventions that suppress inflammation in acute kidney injury, e.g. by blocking pro-inflammatory cytokines and chemokines or by ablating pro-inflammatory leukocyte subsets, largely abrogates tubular cell necrosis and the clinical syndrome of acute renal failure [15]. Tubular necrosis exposes danger signals from dying tubular cells or the tubular lumen to Toll-like receptors or the NLRP3 inflammasome in renal dendritic cells, which sets-off the inflammatory response [16-19]. Also crystal-induced renal inflammation and kidney injury largely depend on NLRP3 inflammasome-mediated induction of interleukin- $1 \beta$ secretion by renal dendritic cells [20]. Innate immunity also drives C3 glomerulopathy where glomerular complement activation is independent of immune complex disease [21]. Innate immunity orchestrates immediate host defense during infective pyelonephritis with uropathogenic bacteria, which may drive renal abscess formation as a form of collateral tissue damage [22,23]. Neutrophil recruitment and neutrophil-mediated immunopathology is a major element of renal immunopathology in renal infection but also in acute tubular necrosis or renal vasculitis, in which innate immunity plays a major role. Finally, even in those diseases that are not directly triggered by immune mechanisms, innate immunity is at least involved in that inflammation that comes with tissue remodeling. Macrophage infiltrates do not always necessarily contribute to renal injury but also to wound healing [24] as macrophage depletion in the healing phase of kidney injury delays kidney regeneration [25-27]. In addition, the role of such wound-healing macrophage phenotypes in driving kidney fibrosis is well established [28]. As such innate immunity is involved in tissue remodeling of all chronic and progressive kidney diseases even such as diabetic nephropathy, Alport nephropathy or polycystic kidney disease [29-32].

But where is the field going? The complex cross-talk between innate and adaptive immunity remains a challenge also for the future [33]. For example, ischemiareperfusion injury is a trigger of renal allograft rejection but how does that work mechanistically $[34,35]$ ? How can monocytes confer allorecognition [36]? What is the role of the recently described innate lymphocytes in kidney disease [37]? How do $\gamma \delta T$ cells, NKT cells, and B1 cells link innate and adaptive immunity in kidney 
disease? Can the immunosuppressive potential of regulatory $\mathrm{T}$ cells be used for therapeutic purposes? What are the innate and what are the adaptive immune functions of the spectrum of the mononuclear phagocyte phenotypes inside the kidney [38]? And finally, when will we finally implement the novel immunoregulatory drugs that are so successful in other medical disciplines also into treatments for patients with kidney diseases? These and other exciting questions are awaiting to be addressed by nephro-immunologists at the bench and immuno-nephrologists at bedside.

\section{Competing interests}

The author declares that he has no competing interests.

Received: 26 April 2013 Accepted: 20 June 2013

Published: 8 July 2013

\section{References}

1. Medzhitov R: Origin and physiological roles of inflammation. Nature 2008, 454(7203):428-435.

2. Anders $\mathrm{HJ}$ : Four danger response programs determine glomerular and tubulointerstitial kidney pathology: clotting, inflammation, epithelial and mesenchymal healing. Organogenesis 2012, 8(2):29-40.

3. Silverstein AM (Ed): A history of Immunology. San Diego: Academic Press; 1989

4. Ritz E, Koleganova N, Heidland A: Renal research in 19th century Germany. Am J Kidney Dis 2010, 55(6):1121-1129.

5. Weening J, Jennette JC: Historical milestones in renal pathology. Virchows Arch 2012, 461(1):3-11.

6. Neilson EG, Couser WG (Eds): Immunologic renal diseases. Philadelphia: Lippincott-Raven; 1997.

7. Anders HJ, Vielhauer V, Schlondorff D: Chemokines and chemokine receptors are involved in the resolution or progression of renal disease. Kidney Int 2003, 63(2):401-415.

8. Lemaitre B: The road to Toll. Nat Rev Immunol 2004, 4(7):521-527.

9. Takeuchi $O$, Akira S: Pattern recognition receptors and inflammation Cell 2010, 140(6):805-820.

10. Schroder K, Tschopp J: The inflammasomes. Cell 2010, 140(6):821-832

11. Medzhitov R, Janeway C Jr: Innate immunity. N Engl J Med 2000, 343(5):338-344

12. Cooper MD, Herrin BR: How did our complex immune system evolve? Nat Rev Immunol 2010, 10(1):2-3.

13. Murphy KM (Ed): Janeways's Immunobiology. 8th edition. New York: Garland Science; 2012.

14. Bonventre $\mathrm{JV}$, Zuk A: Ischemic acute renal failure: an inflammatory disease? Kidney Int 2004, 66(2):480-485

15. Bonventre JV, Yang L: Cellular pathophysiology of ischemic acute kidney injury. J Clin Invest 2011, 121(11):4210-4221

16. Allam R, Scherbaum CR, Darisipudi MN, Mulay SR, Hagele H, Lichtnekert J, Hagemann JH, Rupanagudi KV, Ryu M, Schwarzenberger C, et al: Histones from dying renal cells aggravate kidney injury via TLR2 and TLR4. J Am Soc Nephrol 2012, 23(8):1375-1388.

17. Darisipudi MN, Thomasova D, Mulay SR, Brech D, Noessner E, Liapis H, Anders HJ: Uromodulin triggers IL-1beta-dependent innate immunity via the NLRP3 inflammasome. J Am Soc Nephrol 2012, 23(11):1783-1789.

18. Saemann MD, Weichhart T, Zeyda M, Staffler G, Schunn M, Stuhlmeier KM, Sobanov Y, Stulnig TM, Akira S, von Gabain A, et al: Tamm-Horsfall glycoprotein links innate immune cell activation with adaptive immunity via a Toll-like receptor-4-dependent mechanism. J Clin Invest 2005, 115(2):468-475.

19. Wu H, Ma J, Wang P, Corpuz TM, Panchapakesan U, Wyburn KR, Chadban SJ: HMGB1 contributes to kidney ischemia reperfusion injury. J Am Soc Nephrol 2010, 21(11):1878-1890.

20. Mulay SR, Kulkarni OP, Rupanagudi KV, Migliorini A, Darisipudi MN, Vilaysane A, Muruve D, Shi Y, Munro F, Liapis H, et al: Calcium oxalate crystals induce renal inflammation by NLRP3-mediated IL-1beta secretion. J Clin Invest 2013, 123(1):236-246.
21. Bomback AS, Appel GB: Pathogenesis of the C3 glomerulopathies and reclassification of MPGN. Nat Rev Nephrol 2012, 8(11):634-642.

22. Tittel AP, Heuser C, Ohliger C, Knolle PA, Engel DR, Kurts C: Kidney dendritic cells induce innate immunity against bacterial pyelonephritis. J Am Soc Nephrol 2011, 22(8):1435-1441.

23. Patole PS, Schubert S, Hildinger K, Khandoga S, Khandoga A, Segerer S, Henger A, Kretzler M, Werner M, Krombach F, et al: Toll-like receptor-4: renal cells and bone marrow cells signal for neutrophil recruitment during pyelonephritis. Kidney Int 2005, 68(6):2582-2587.

24. Anders HJ, Ryu M: Renal microenvironments and macrophage phenotypes determine progression or resolution of renal inflammation and fibrosis. Kidney Int 2011, 80(9):915-925.

25. Kim MG, Boo CS, Ko YS, Lee HY, Cho WY, Kim HK, Jo SK: Depletion of kidney $C D 11 c+F 4 / 80+$ cells impairs the recovery process in ischaemia/ reperfusion-induced acute kidney injury. Nephrol Dial Transplant 2010, 25(9):2908-2921.

26. Lee S, Huen S, Nishio H, Nishio S, Lee HK, Choi BS, Ruhrberg C, Cantley LG: Distinct macrophage phenotypes contribute to kidney injury and repair. J Am Soc Nephrol 2011, 22(2):317-326.

27. Zhang MZ, Yao B, Yang S, Jiang L, Wang S, Fan X, Yin H, Wong K, Miyazawa T, Chen J, et al: CSF-1 signaling mediates recovery from acute kidney injury. J Clin Invest 2012, 122(12):4519-4532.

28. Lech M, Anders HJ: Macrophages and fibrosis: How resident and infiltrating mononuclear phagocytes orchestrate all phases of tissue injury and repair. Biochim Biophys Acta 2012, 1832(7):989-97.

29. Swenson-Fields KI, Vivian CJ, Salah SM, Peda JD, Davis BM, van Rooijen N, Wallace DP, Fields TA: Macrophages promote polycystic kidney disease progression. Kidney Int 2013, 83(5):855-64.

30. Ryu M, Kulkarni OP, Radomska E, Miosge N, Gross O, Anders HJ: Bacterial CpG-DNA accelerates Alport glomerulosclerosis by inducing an M1 macrophage phenotype and tumor necrosis factor-alpha-mediated podocyte loss. Kidney Int 2011, 79(2):189-198.

31. Ninichuk V, Gross O, Reichel C, Khandoga A, Pawar RD, Ciubar R, Segerer S, Belemezova E, Radomska E, Luckow B, et al: Delayed chemokine receptor 1 blockade prolongs survival in collagen 4A3-deficient mice with Alport disease. J Am Soc Nephrol 2005, 16(4):977-985.

32. Navarro-Gonzalez JF, Mora-Fernandez C, Muros de Fuentes M, Garcia-Perez J: Inflammatory molecules and pathways in the pathogenesis of diabetic nephropathy. Nat Rev Nephrol 2011, 7(6):327-340.

33. Biron CA: More things in heaven and earth: defining innate and adaptive immunity. Nat Immunol 2010, 11(12):1080-1082.

34. Leventhal JS, Schroppel B: Toll-like receptors in transplantation: sensing and reacting to injury. Kidney Int 2012, 81(9):826-832.

35. Oberbarnscheidt MH, Zecher D, Lakkis FG: The innate immune system in transplantation. Semin Immunol 2011, 23(4):264-272.

36. Zecher D, van Rooijen N, Rothstein DM, Shlomchik WD, Lakkis FG: An innate response to allogeneic nonself mediated by monocytes. J Immunol 2009, 183(12):7810-7816

37. Spits H, Di Santo JP: The expanding family of innate lymphoid cells: regulators and effectors of immunity and tissue remodeling. Nat Immunol 2011, 12(1):21-27.

38. Nelson PJ, Rees AJ, Griffin MD, Hughes J, Kurts C, Duffield J: The renal mononuclear phagocytic system. J Am Soc Nephrol 2012, 23(2):194-203.

doi:10.1186/1471-2369-14-138

Cite this article as: Anders: Innate versus adaptive immunity in kidney immunopathology. BMC Nephrology 2013 14:138. 